\title{
Meta-Analysis the Effects of Non Exclusive Breastfeeding and Inappropriate Complementary Feeding on Stunting in Children Under Five
}

\author{
Tyas Aisyah Putri'), Yulia Lanti Retno Dewi²), Bhisma Murti') \\ ${ }^{1)}$ Masters Program in Public Health, Universitas Sebelas Maret \\ ${ }^{2)}$ Department in Nutrition, Faculty of Medicine, Universitas Sebelas Maret
}

\section{ABSTRACT}

Background: One of the Sustainable Development Goals (SDGs) targets in 2030 is to end all forms of malnutrition, including reducing stunting, which is still a global problem. Stunting is directly and negatively affected by birth length, exclusive breastfeeding, and complementary feeding on time. This study aims to estimate the magnitude of the effect of nonexclusive breastfeeding and inappropriate complementary breastfeeding on the incidence of stunting in children under five using a metaanalysis study.

Subjects and Method: This meta-analysis study was conducted by selecting articles published in the years 2010-2020, from the PubMed, Google Scholar, and BMJ databases. Article searches are carried out by considering the eligibility criteria. This article was collected for 1 month using the following keywords: "Exclusive Breastfeeding" AND "Complementary Feeding" AND "Stunting". The inclusion criteria were full text study, children under five years of age, non-exclusive breastfeeding intervention and complementary feeding were not on time, the outcome of the article was stunting by observational study, and the results were reported in adjusted odds ratio (aOR). Eligible articles were analyzed using Review Manager 5.3 program.

Results: Fifteen articles were reviewed in this study with a cross sectional and case control study design. Meta analysis of 7 case control studies showed that children under five who were not exclusively breastfed had a risk of stunting $(\mathrm{aOR}=2.83 ; 95 \% \mathrm{CI}=1.30$ to $4.53 ; \mathrm{p}=$ o.006), 3 cross-sectional studies showed that children under five who were not exclusively breastfed had a risk of stunting $(\mathrm{aOR}=1.41$; $95 \% \mathrm{CI}=1.30$ to $4.53 ; \mathrm{p}=0.69$ ), and 5 crosssectional studies showed that children under five who were breastfed inappropriately have a risk of stunting $(\mathrm{aOR}=2.46 ; 95 \% \mathrm{CI}=1.81$ to 3.36; $\mathrm{p}<0.001$ ).

Conclusion: Non-exclusive breastfeeding and MP ASI not on time have a risk of stunting.

Keywords: Stunting, exclusive breastfeeding, complementary breastfeeding, meta-analysis

\section{Correspondence:}

Tyas Aisyah Putri. Masters Program in Public Health, Universitas Sebelas Maret, Jl. Ir. Sutami 36A, Surakarta 57126, Central Java. Email: taisyah1996@gmail.com. Mobile: +6285725003949.

Cite this as:

Putri TA, Dewi YLR, Murti B (2020). Meta-Analysis the Effects of Non Exclusive Breastfeeding and Inappropriate Complementary Feeding on Stunting in Children Under Five. J Matern Child Health. 05(05): 514-524. https://doi.org/10.26911/thejmch.2020.05.05.06. cc) (1) (5) Journal of Maternal and Child Health is licensed under a Creative Commons

\section{BACKGROUND}

Ending all forms of malnutrition including achieving the international target of 2025 for the reduction of stunting and wasting by 2030 is one of the goals (Indonesia Health Profile, 2015).
Stunting is defined as low height for age. Stunting inhibits the physical and cognitive potential of children (WHO, 2020). Stunting is directly and negatively affected by birth length, exclusive breastfeeding, and complementary feeding on 
time. Stunting is indirectly influenced by family income, maternal age, mother's attitude, mother's height $>150 \mathrm{~cm}$, working mothers, mother's education, and mother's knowledge (Barir, 2019).

In 2018, stunting affected estimated $21.9 \%$ or 149 million children under 5 years of age. The prevalence of stunting under five in Indonesia in 2010 was $35.6 \%$, then in 2013 it increased to $37.2 \%$. In 2018 it decreased to $30.8 \%$, this number has decreased but is still below WHO recommendations (Ministry of Health, 2018).

Nutritional problems in toddlers in the short term can cause adverse effects, including disruption of brain development, intelligence, physical growth disorders, and metabolic disorders in the body. The longterm impact of the bad consequences that can be caused is decreased cognitive abilities and learning achievement, decreased immunity so that they get sick easily, and a high risk for diabetes, obesity, and uncompetitive quality of work which results in low economic productivity (Pusdatin, 2016) .

Meta analysis is an epidemiological design that aims to systematically study and combine the results of quantitative estimates from a number of previous studies that answer the same research problems and can be combined. Many primary studies have conducted the effect of a history of exclusive breastfeeding and complementary breastfeeding on the incidence of stunting in children under five. Further analysis is needed to arrive at conclusive conclusions. This study aimed to examine the effect of non-exclusive breastfeeding and inappropriate complementary feeding on the incidence of stunting".

\section{SUBJECTS AND METHOD}

\section{StudyDesign}

This study uses a systematic review study and meta-analysis. The articles in this study were obtained from several databases including PubMed, Google Scholar, and BMJ. Articles are collected for 1 month. The keyword search for the article is to use the following: "Exclusive Breastfeeding" AND "Complementary Feeding" AND "Stunting".

\section{InclusionCriteria}

The articles included in this research are full text articles. The research subjects were children under five years of age, the interventions given were non-exclusive breastfeeding and complementary foods that were not on time, the outcome of the article was stunting, with observational studies, and the analysis used multivariate with adjusted odds ratio (aOR).

\section{ExclusionCriteria}

The articles published in this study are articles that have been published where metaanalysis has been carried out and articles are not in English and in Indonesian

\section{Operational definition of variables}

The article search was carried out by considering the eligibility criteria defined using the PICO model. The population in the study were children under five years of age with non-exclusive breastfeeding intervention and complementary foods that were not on time, the comparison was exclusive breastfeeding, complementary foods on time, and the outcome was stunting.

Non-exclusive breastfeeding was when a child has received additional food or drink from birth to 6 months of age. The instrument used was a questionnaire with a categorical measuring scale.

Inappropriate complementary feeding was the child gets additional food other than ASI or PASI given before or more than 6 months of age. The instrument used was a questionnaire with a categorical measuring scale.

Stunting was body length or height according to age with a z-score between -3 
Putri et al./ Non Exclusive Breastfeeding, Complementary Feeding, and Stunting

SD to less than -2 SD. The instruments used are in the form of a stature meter or microtoice and a scale with a continuous measuring scale.

\section{DataAnalysis}

Data processing was carried out by the Review Manager (RevMan 5.3) by calculating the adjusted Odds Ratio and heterogeneity to determine which research models were combined and formed the final meta-analysis result.

\section{RESULTS}

The process of searching for articles through a database with journals can be seen in Figure 1.

\begin{tabular}{|c|c|}
\hline $\begin{array}{c}\text { Identified articles from online } \\
\text { databases }(n=5,483)\end{array}$ & Deleting multiple data $(\mathrm{n}=1,857)$ \\
\hline 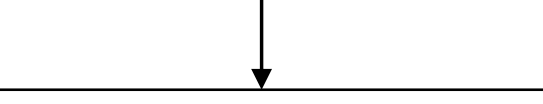 & $\begin{array}{l}\text { Drop out articles }(n=3,102) \\
\text { Irrelevant title }(n=2,604)\end{array}$ \\
\hline Filtered articles $(n=3,626)$ & Non cross-sectional and case control study \\
\hline & $\begin{array}{l}\text { Non English or Indonesian language }(n=17) \\
\text { Non full text articles }(n=154)\end{array}$ \\
\hline Full text articles that met the & $\begin{array}{l}\text { Drop out full text that did not met the } \\
\text { criteria }(n=509)\end{array}$ \\
\hline & Stunting was not used as outcome $(n=16)$ \\
\hline$\downarrow$ & breastfeeding and inappropriate \\
\hline $\begin{array}{l}\text { Articles selected for meta } \\
\text { analysis }(n=15)\end{array}$ & $\begin{array}{l}\text { complementary feeding }(n=269) \\
\text { Did not report aOR }(n=224)\end{array}$ \\
\hline
\end{tabular}

Figure 1. PRISMA flow diagram

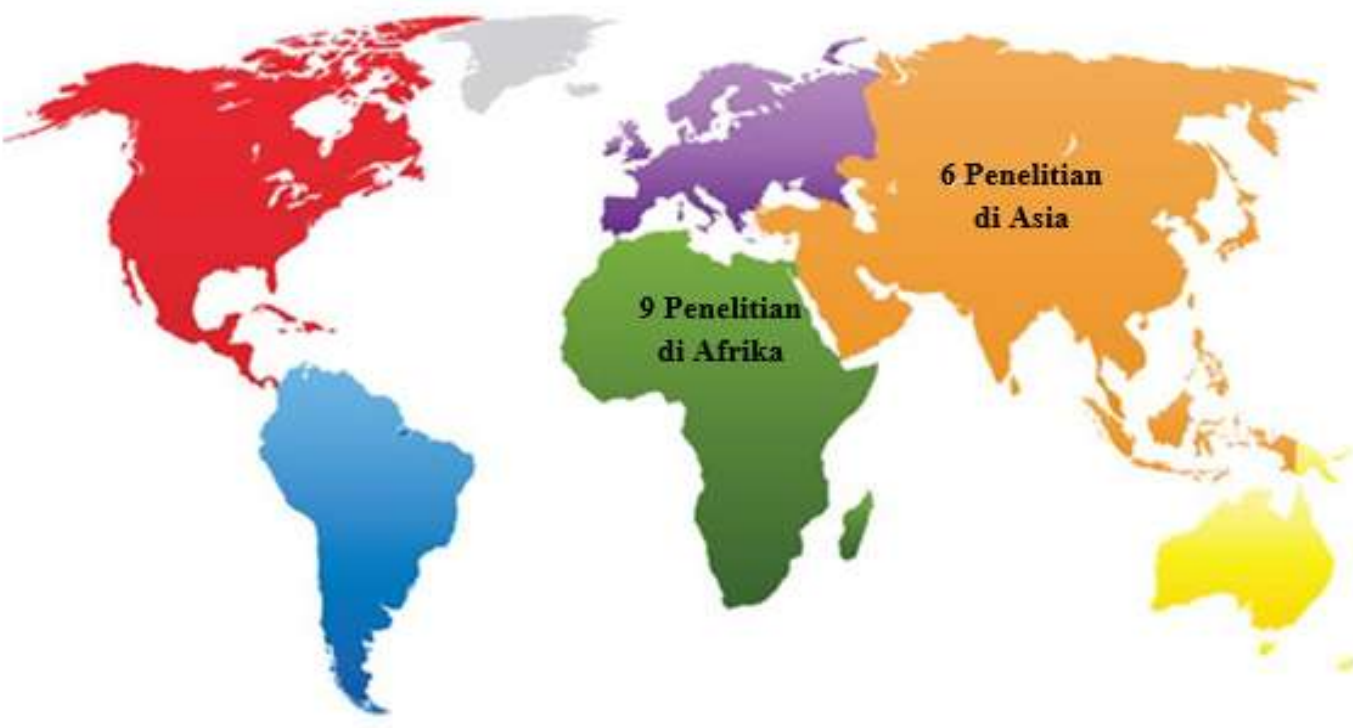

Figure 2. Map of the research area 
Putri et al./ Non Exclusive Breastfeeding, Complementary Feeding, and Stunting

The area where the articles were taken according to the inclusion criteria can be seen in Figure 2. The articles were obtained from 2 continents, namely Asia and Africa.

Assessment of the quality of the study in this study used the following 12 questions for the Critical Appraisal Checklist for Cross sectional Study (CEBMa, 2014): 1) Does this objective clearly address the focus /research problem?; 2) Is the research method (research design) appropriate for answering research questions?; 3) Is the method of selecting research subjects written clearly?; 4) Does the sampling method lead to bias (selection)?; 5) Does the research sample taken represent the designated population?; 6) Was the sample size based on pre-study considerations?; 7) Was a satisfactory response achieved?; 8) Is the research instrument valid and reliable?; 9) Is statistical significance assessed?; 10) Are confidence intervals given for the main outcome?; 11) Are there any confounding factors that have not been taken into account?; 12) Are the results applicable to your research? Then each question is given a score with 1 saying "yes" and o saying "no". The results of the study quality assessment are shown in Table 1 . As well as the 12 Critical Apparisal for Case Control Study questions (CEBMa, 2014) as follows: 1) Does this study address clearly focused questions/ problems?; 2) Is the research method (study design) appropriate to answer the research question?; 3) Are there enough subjects (employees, teams, divisions, organizations) in the study to establish that the findings did not occur by chance ?; 4) Is the selection of cases and controls based on external, objective and validated criteria ?; 5) Were the two groups comparable at the start of the study ?; 6) Are the outcome criteria objective and unbiased?; 7) Is there data dredging?; 8) Are objective and validated measurement methods used to measure results? If not, were the results scored by someone who did not know the group assignment (eg was the rater blind)?; 9) Is the effect size practically relevant?; 10) How precise is the estimated effect? Is the confidence interval granted ?; 11) Could there be confounding factors that have not been taken into account?; 12) Can the results be applied to your organization? Then each question is given a score with 1 stating "yes" and o saying "no". The results of the study quality assessment are shown in Table 2.

Table 4 shows that there are 7 articles of case control studies and 3 articles of cross sectional studies as evidence of the relationship between the effect of nonexclusive breastfeeding on the incidence of stunting.

Table 1. Assessment of Research Quality using Critical Appraisal Questions for Case control Study The effect of non-exclusive breastfeeding on stunting

\begin{tabular}{|c|c|c|c|c|c|c|c|c|c|c|c|c|c|}
\hline \multirow{2}{*}{ Author (Year) } & \multicolumn{12}{|c|}{ Checklists } & \multirow{2}{*}{ Total } \\
\hline & $\mathbf{1}$ & 2 & 3 & 4 & 5 & 6 & 7 & 8 & 9 & 10 & $\mathbf{1 1}$ & 12 & \\
\hline Alifariki et al (2020) & 1 & 1 & 1 & 1 & 1 & 1 & 0 & 1 & 0 & 1 & 1 & 1 & 10 \\
\hline Kahssayet al (2020) & 1 & 1 & 1 & 0 & 1 & 1 & $\mathrm{O}$ & 1 & 1 & 1 & $\mathrm{O}$ & 1 & 9 \\
\hline Tadessee et al. (2020) & 1 & 1 & 1 & 1 & 1 & 1 & $\mathrm{O}$ & 1 & 1 & 1 & 1 & 1 & 11 \\
\hline Fikadu et al.(2014) & 1 & 1 & 1 & 1 & 1 & O & 0 & 1 & 1 & 1 & 1 & 1 & 10 \\
\hline Taufiqoh et al. (2017) & 1 & 1 & 1 & 1 & 1 & $\mathrm{O}$ & $\mathrm{O}$ & 1 & 1 & 1 & 1 & 1 & 10 \\
\hline Rahayu et al (2018) & 1 & 1 & 1 & 1 & 1 & 1 & 1 & 1 & 1 & 1 & 1 & 1 & 12 \\
\hline Al-Rahmad et al (2013) & 1 & 1 & 1 & 1 & 1 & 1 & $\mathrm{O}$ & 1 & 1 & 1 & 1 & 1 & 11 \\
\hline
\end{tabular}


Putri et al./ Non Exclusive Breastfeeding, Complementary Feeding, and Stunting

Table 2. Research Quality Assessment using the Critical Appraisal Checklist for Cross sectional Study The effect of non-exclusive breastfeeding on stunting

\begin{tabular}{|c|c|c|c|c|c|c|c|c|c|c|c|c|c|}
\hline \multirow{2}{*}{ Author (Year) } & \multicolumn{12}{|c|}{ Checklists } & \multirow{2}{*}{ Total } \\
\hline & $\mathbf{1}$ & 2 & 3 & 4 & 5 & 6 & 7 & 8 & 9 & 10 & 11 & 12 & \\
\hline Dessie et al. (2018) & 1 & 1 & 1 & 1 & 1 & $\mathrm{O}$ & 1 & 1 & 1 & 1 & 0 & 1 & 10 \\
\hline Abebe et al. (2017) & 1 & 1 & 1 & $\mathrm{O}$ & 1 & 1 & 1 & 1 & 1 & 1 & 0 & 1 & 10 \\
\hline Wahdah et al (2015) & 1 & 1 & 1 & 1 & 1 & 1 & 1 & 1 & 1 & 1 & 0 & 1 & 11 \\
\hline
\end{tabular}

Table 3.Research Quality Assessment using Critical Appraisal Checklist for Cross sectional Study Effect of inappropriate complementary breastfeeding on stunting

\begin{tabular}{|c|c|c|c|c|c|c|c|c|c|c|c|c|c|}
\hline \multirow{2}{*}{ Author (Year) } & \multicolumn{12}{|c|}{ Checklists } & \multirow{2}{*}{ Total } \\
\hline & 1 & 2 & 3 & 4 & 5 & 6 & 7 & 8 & 9 & 10 & $\mathbf{1 1}$ & 12 & \\
\hline Abewayet al. (2018) & 1 & 1 & 1 & O & 1 & 1 & 1 & 1 & 1 & 1 & $\mathrm{O}$ & 1 & 10 \\
\hline Demilewet al. (2017) & 1 & 1 & 1 & 1 & 1 & 1 & 1 & 1 & 1 & 1 & 0 & 1 & 11 \\
\hline Beteboet al. (2017) & 1 & 1 & 1 & $\mathrm{O}$ & 1 & 1 & 1 & 1 & 1 & 1 & $\mathrm{O}$ & 1 & 11 \\
\hline Teferiet al. (2016) & 1 & 1 & 1 & 1 & 1 & 1 & 1 & 1 & 1 & 1 & 0 & 1 & 11 \\
\hline Ranti (2018) & 1 & 1 & $\mathrm{O}$ & 1 & 1 & 1 & 1 & 1 & 1 & 1 & O & 1 & 10 \\
\hline
\end{tabular}

Figure 3 shows the forest plot results from the results of the sub-group analysis with two study designs. The case control study design showed that non-exclusive breastfeeding increased the incidence of stunting by 2.83 times compared to exclusive breastfeeding with statistical significance $(\mathrm{aOR}=2.83 ; 95 \% \mathrm{CI}=1.30$ to 4.53 ; $\mathrm{p}=0.006)$. The study heterogeneity of the data showed $\mathrm{I}^{2}=79 \%$ so that the distribution of the data was stated as heterogeneous (random effect model).

Meanwhile, the cross sectional design shows that non-exclusive breastfeeding can increase the incidence of stunting by 1.41 times compared to exclusive breastfeeding with statistical significance $(\mathrm{aOR}=1.41$; $95 \% \mathrm{CI}=1.30$ to $4.53 ; \mathrm{p}=0.69$ ). The heterogeneity of the research data showed $\mathrm{I}^{2}=$ $85 \%$ so that the distribution of the data was stated as heterogeneous (random effect model).

The funnel plot shows a publication bias which is characterized by asymmetry of the right and left plots where 7 plots are on the right and 2 plots are on the left and 1 plot touches the line. The plot on the right of the graph appears to have a standard error between 0.2 and 0.7 and the plot on the left has a standard error between 0.4 and 1. The bias also occurs from an imbalance between the distances between studies on both the right and left of the funnel plot. This is shown in Figure 4.

Table 5 shows that there are 5 crosssectional study articles as evidence of the relationship between the effect of inappropriate complementary breastfeeding on the incidence of stunting. Figure 5 shows the results of the forest plot with a cross sectional study design showing that complementary feeding without time can increase the incidence of stunting by 2.46 times compared to exclusive breastfeeding and statistically significant $(\mathrm{aOR}=2.46 ; 95 \%$ $\mathrm{CI}=1.81$ to $3.36 ; \mathrm{p}=0.001)$. The heterogeneity of the research data shows $\mathrm{I}^{2}=0 \%$ so that the distribution of the data is declared homogeneous (fixed effect model). 
Putri et al./ Non Exclusive Breastfeeding, Complementary Feeding, and Stunting

Table 4. Description of the primary study meta-analysis of the effect of non-exclusive breastfeeding on the incidence of stunting

\begin{tabular}{|c|c|c|c|c|c|c|c|}
\hline Author (year) & Countru & $\begin{array}{l}\text { Study } \\
\text { Design }\end{array}$ & Sample & Population & Intervention & Comparison & Outcome \\
\hline $\begin{array}{l}\text { Alifariki et al. } \\
(2020)\end{array}$ & Indonesia & $\begin{array}{l}\text { Case } \\
\text { control }\end{array}$ & 108 & $\begin{array}{l}\text { Toddler aged } \\
24-59 \text { months }\end{array}$ & $\begin{array}{l}\text { Not getting exclusive } \\
\text { breastfeeding }\end{array}$ & $\begin{array}{l}\text { Receive exclusive } \\
\text { breastfeeding }\end{array}$ & Stunting \\
\hline $\begin{array}{l}\text { Kahssay et al. } \\
(2020)\end{array}$ & Ethiopia & $\begin{array}{l}\text { Case } \\
\text { control }\end{array}$ & 322 & $\begin{array}{l}\text { Toddler aged } \\
6-59 \text { months }\end{array}$ & $\begin{array}{l}\text { Not getting exclusive } \\
\text { breastfeeding }\end{array}$ & $\begin{array}{l}\text { Receive exclusive } \\
\text { breastfeeding }\end{array}$ & Stunting \\
\hline $\begin{array}{l}\text { Tadesse et al. } \\
(2020)\end{array}$ & Ethiopia & $\begin{array}{l}\text { Case } \\
\text { control }\end{array}$ & 321 & $\begin{array}{l}\text { Toddler aged } \\
6-59 \text { months }\end{array}$ & $\begin{array}{l}\text { Duration of exclusive } \\
\text { breastfeeding < <r }>6 \text { months }\end{array}$ & $\begin{array}{l}\text { The duration of exclusive } \\
\text { breastfeeding is } 6 \text { months }\end{array}$ & Stunting \\
\hline $\begin{array}{l}\text { Fikadu et al. } \\
(2014)\end{array}$ & Ethiopia & $\begin{array}{l}\text { Case } \\
\text { control }\end{array}$ & 242 & $\begin{array}{l}\text { Toddler aged } \\
\text { 24-59 months }\end{array}$ & $\begin{array}{l}\text { Duration of exclusive } \\
\text { breastfeeding }<6 \text { months }\end{array}$ & $\begin{array}{l}\text { The duration of exclusive } \\
\text { breastfeeding is } 6 \text { months }\end{array}$ & Stunting \\
\hline $\begin{array}{l}\text { Taufiqoh et al. } \\
\text { (2017) }\end{array}$ & Indonesia & $\begin{array}{l}\text { Case } \\
\text { control }\end{array}$ & 118 & $\begin{array}{l}\text { Toddlers aged } \\
12-59 \text { months }\end{array}$ & $\begin{array}{l}\text { History of breastfeeding is not } \\
\text { exclusive }\end{array}$ & $\begin{array}{l}\text { Exclusive breastfeeding } \\
\text { history }\end{array}$ & Stunting \\
\hline $\begin{array}{l}\text { Rahayu et al. } \\
\text { (2018) }\end{array}$ & Indonesia & $\begin{array}{l}\text { Case } \\
\text { control }\end{array}$ & 150 & $\begin{array}{l}\text { Toddlers aged } \\
12-48 \text { months }\end{array}$ & Status not exclusively breastfed & $\begin{array}{l}\text { Exclusive breastfeeding } \\
\text { status }\end{array}$ & Stunting \\
\hline $\begin{array}{l}\text { Al-Rahmad et al. } \\
(2013)\end{array}$ & Indonesia & $\begin{array}{l}\text { Case } \\
\text { control }\end{array}$ & 96 & $\begin{array}{l}\text { Toddler aged } \\
12-60 \text { months }\end{array}$ & Breastfeeding is not exclusive & Exclusive breastfeeding & Stunting \\
\hline Dessie et al.(2018) & Ethiopia & $\begin{array}{l}\text { Cross } \\
\text { sectional }\end{array}$ & 554 & $\begin{array}{l}\text { Toddler aged } \\
6-59 \text { months }\end{array}$ & $\begin{array}{l}\text { Not getting exclusive breastfeed- } \\
\text { ing for at least } 6 \text { months }\end{array}$ & $\begin{array}{l}\text { Get exclusive breastfeed- } \\
\text { ing for } 6 \text { months }\end{array}$ & Stunting \\
\hline Abebe et al.(2017) & Ethiopia & $\begin{array}{l}\text { Cross } \\
\text { sectional }\end{array}$ & 764 & $\begin{array}{l}\text { Toddler aged } \\
6-59 \text { months }\end{array}$ & $\begin{array}{l}\text { Not exclusively breastfed for the } \\
\text { first } 6 \text { months }\end{array}$ & $\begin{array}{l}\text { Was exclusively breastfed } \\
\text { for the first } 6 \text { months }\end{array}$ & Stunting \\
\hline $\begin{array}{l}\text { Wahdah et } \\
\text { al.(2015) }\end{array}$ & Indonesia & $\begin{array}{l}\text { Cross } \\
\text { sectional }\end{array}$ & 120 & $\begin{array}{l}\text { Toddler aged } \\
3-36 \text { months }\end{array}$ & Breastfeeding is not exclusive & Exclusive breastfeeding & Stunting \\
\hline
\end{tabular}

Table 5. Description of the primary study meta analysis of the effect of inappropriate complementary breastfeeding on the incidence of stunting

\begin{tabular}{|c|c|c|c|c|c|c|c|}
\hline Author (Year) & Country & $\begin{array}{l}\text { Study } \\
\text { Design }\end{array}$ & Sample & Population & Intervention & Comparison & Outcome \\
\hline $\begin{array}{l}\text { Abeway et al. } \\
(2018)\end{array}$ & Ethiopia & $\begin{array}{c}\text { Cross } \\
\text { sectional }\end{array}$ & 410 & $\begin{array}{l}\text { Toddler aged 6-59 } \\
\text { months }\end{array}$ & $\begin{array}{l}\text { Do not start MP ASI on } \\
\text { time }\end{array}$ & $\begin{array}{l}\text { Complementary feeding } \\
\text { starts at } 6 \text { months of age }\end{array}$ & Stunting \\
\hline $\begin{array}{l}\text { Demilew et al. } \\
\text { (2017) }\end{array}$ & Ethiopia & $\begin{array}{c}\text { Cross } \\
\text { sectional }\end{array}$ & 480 & $\begin{array}{l}\text { Toddlers aged 24- } \\
36 \text { months }\end{array}$ & $\begin{array}{l}\text { MP ASI given }<6 \text { months } \\
\text { or }>6 \text { months }\end{array}$ & $\begin{array}{l}\text { Complementary feeding is } \\
\text { given at } 6 \text { months }\end{array}$ & Stunting \\
\hline $\begin{array}{l}\text { Betebo et al. } \\
(2017)\end{array}$ & Ethiopia & $\begin{array}{c}\text { Cross } \\
\text { sectional }\end{array}$ & 508 & $\begin{array}{l}\text { Toddler aged 6-59 } \\
\text { months }\end{array}$ & $\begin{array}{l}\text { MP ASI }<6 \text { months or }>6 \\
\text { months }\end{array}$ & $\begin{array}{l}\text { Complementary feeding } \\
\text { at } 6 \text { months }\end{array}$ & Stunting \\
\hline Teferi et al. (2016) & Ethiopia & $\begin{array}{l}\text { Cross } \\
\text { sectional }\end{array}$ & 324 & $\begin{array}{l}\text { Toddler aged 6-59 } \\
\text { months }\end{array}$ & $\begin{array}{l}\text { MP ASI starts }<6 \text { or }>6 \\
\text { months }\end{array}$ & $\begin{array}{l}\text { Complementary feeding } \\
\text { starts for } 6 \text { months }\end{array}$ & Stunting \\
\hline Ranti(2018) & Indonesia & $\begin{array}{c}\text { Cross } \\
\text { sectional }\end{array}$ & 101 & $\begin{array}{l}\text { Toddler aged 24- } \\
59 \text { months }\end{array}$ & $\begin{array}{l}\text { MP ASI given at }<6 \\
\text { months }\end{array}$ & $\begin{array}{l}\text { Complementary feeding } \\
\text { at } 6 \text { months }\end{array}$ & Stunting \\
\hline
\end{tabular}


Putri et al./ Non Exclusive Breastfeeding, Complementary Feeding, and Stunting

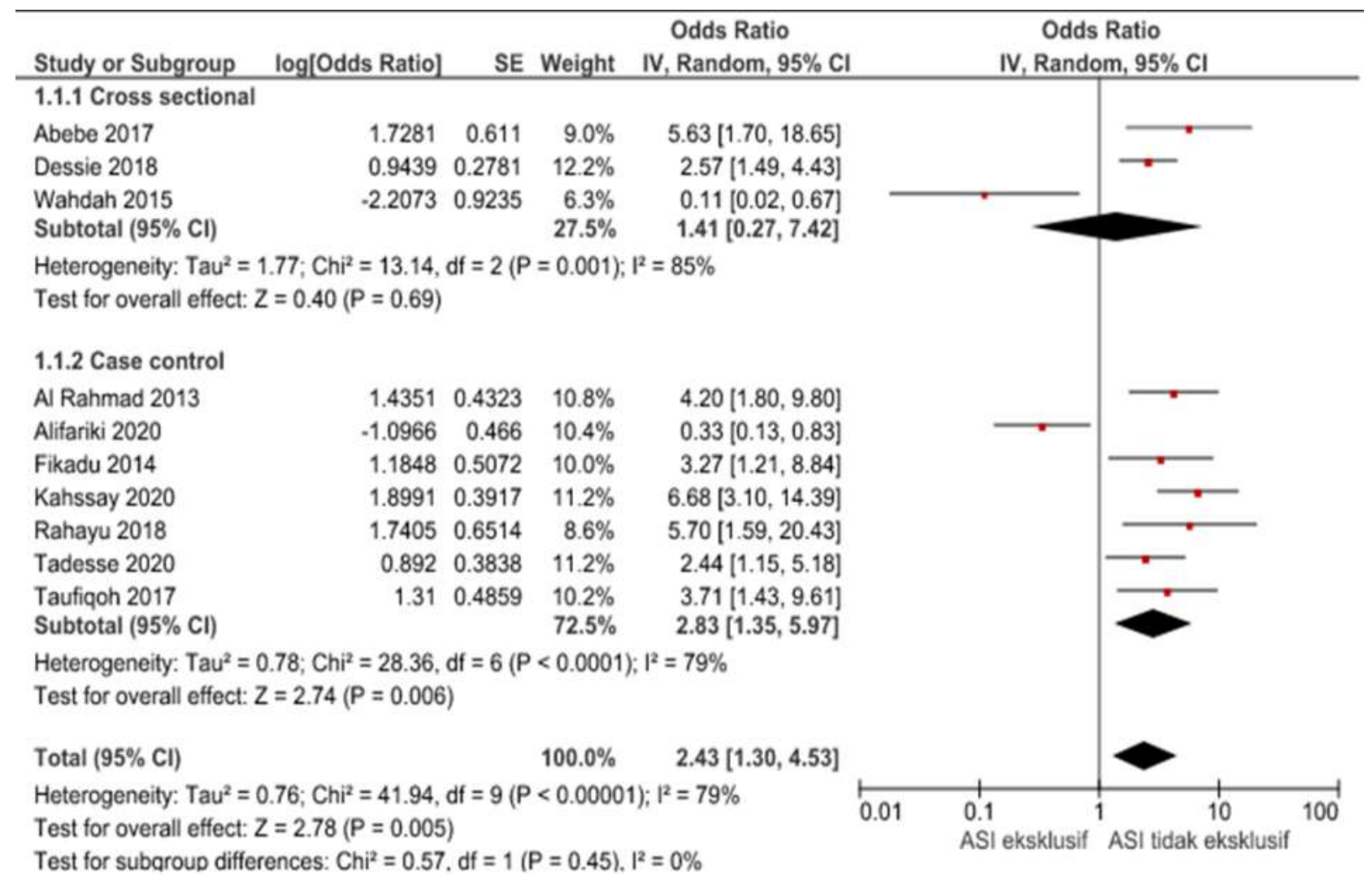

Figure 3. Forest plot meta analysis on the effect of non exclusive breastfeeding on the incidence of stunting

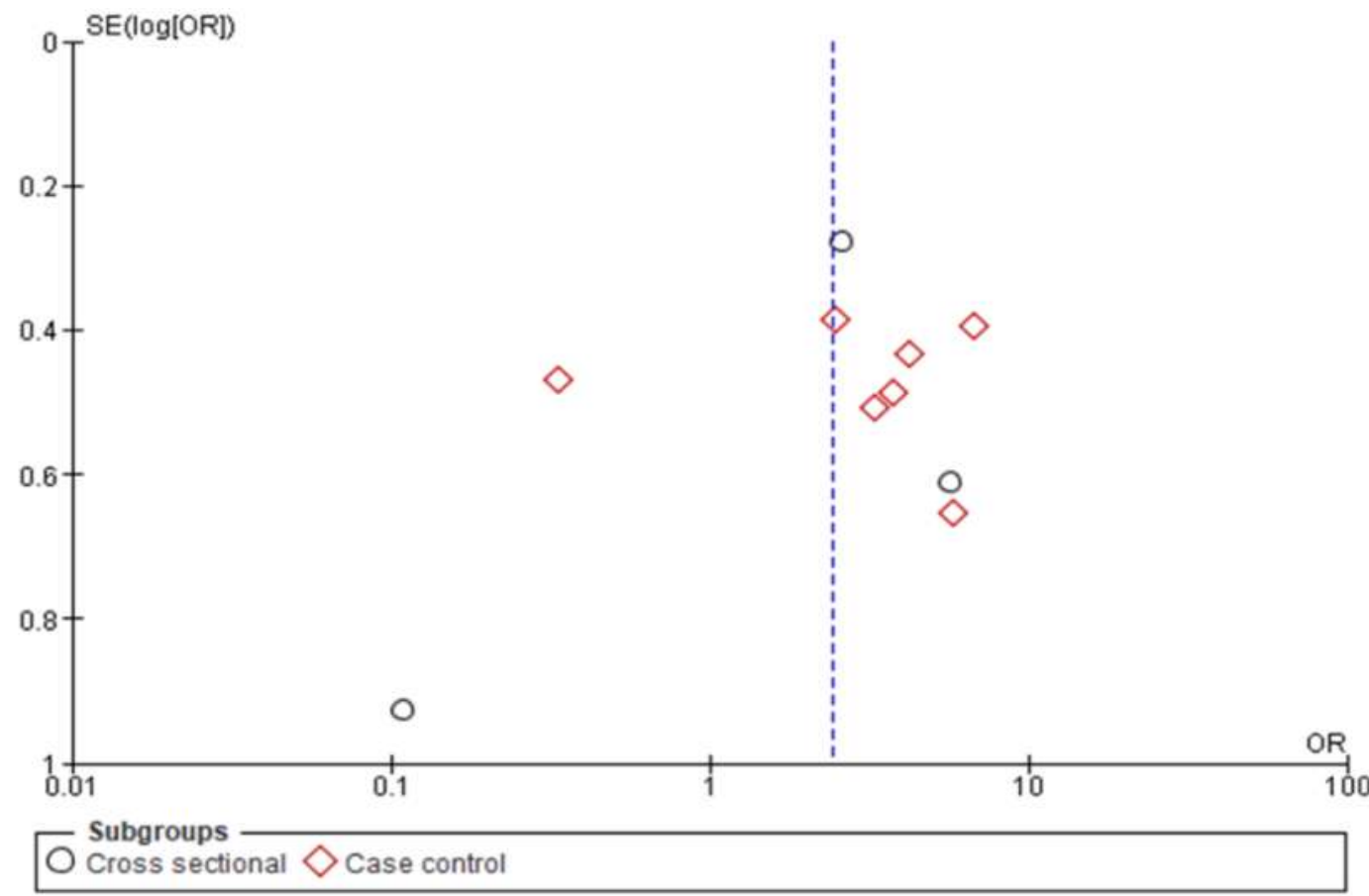

Figure 4. Funnel plot meta analysis of the effect of non-exclusive breastfeeding on the incidence of stunting 
Putri et al./ Non Exclusive Breastfeeding, Complementary Feeding, and Stunting

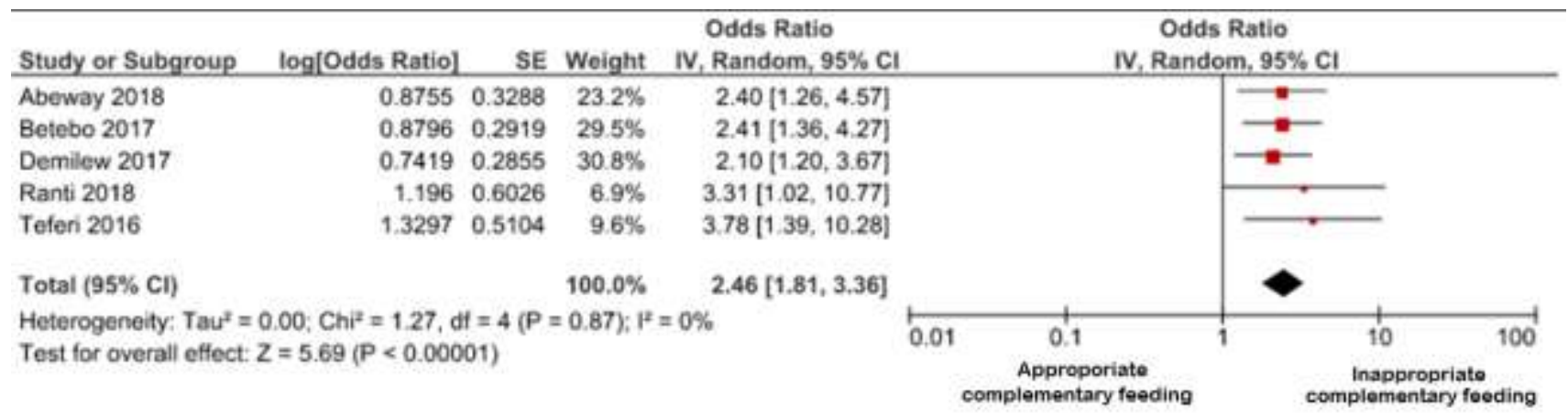

Figure 5. Forest plot meta analysis of the effect of inappropriate complementary feeding on stunting

The funnel plot shows publication bias which is indicated by asymmetry of the right and left plots where 2 plots are on the right and 1 plot is on the left and 1 plot touches the line. The plot on the right of the graph appears to have a standard error

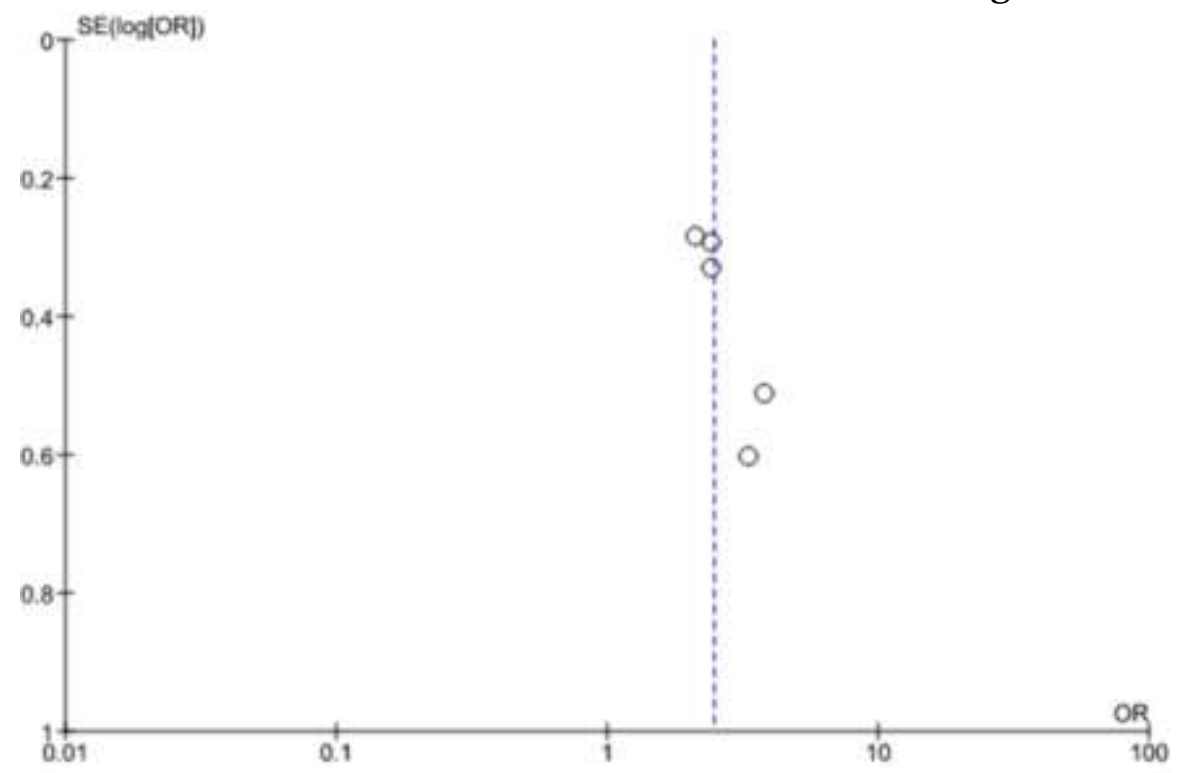

between 0.5 and 0.6 and the plot on the left has a standard error between 0.2 and 0.4 . Bias also occurs from an imbalance between the distances between studies, both on the right and left of the funnel plot. This is shown in Figure 6.

\section{Figure 6. Funnel plot meta analysis of the effect of inappropriate complementary breastfeeding on the incidence of stunting}

\section{DISCUSSION}

The systematic study and meta-analysis research in this study was themed the effect of exclusive breastfeeding and complementary breastfeeding on the incidence of stunting. The independent variables analyzed were non-exclusive ASI and MP ASI was not on time. Research that discusses stunting is considered important because the incidence rate is still quite high in children under five in Indonesia and the world.

This systematic study and meta-analysis research uses research that controls confounding factors which can be seen from the research inclusion requirements, namely multivariate analysis and the statistical results reported are adjusted Odd 
Ratio (aOR). Estimates of the combined effect of non-exclusive breastfeeding and MP ASI were not timely with the incidence of stunting processed using the RevMan 5.3 application with the generic inverse variance method.

\section{Breast milk is not exclusive to stunting}

Forest plot results from research articles with cross sectional study design showed that children under five who were not exclusively breastfed had a 1.41 times risk of increasing the incidence of stunting compared to children under five who were exclusively breastfed $(\mathrm{aOR}=1.41 ; 95 \% \mathrm{CI}=$ 1.30 to $4.53 ; \mathrm{p}=0.69$ ). Whereas a research article with a case control study design showed that children under five who were not exclusively breastfed had a 2.83 times risk of increasing the incidence of stunting compared to children under five who were exclusively breastfed $(\mathrm{aOR}=2.83 ; 95 \% \mathrm{CI}=$ 1.30 to $4.53 ; \mathrm{p}=0.006$ ) .

Exclusive breastfeeding, complementary feeding on time, birth length $\geq 48 \mathrm{~cm}$, and birth weight of infants $\geq 2500 \mathrm{~g}$ are the direct negative effects of stunting (Barir et al, 2019). Appropriate exclusive breastfeeding can provide protection against gastrointestinal infections which can cause depletion of nutrients which lead to growth retardation (Kramer and Kakuma, 2012). Exclusive breastfeeding can reduce the incidence of stunting which has a 0.23 times probability of not being inhibited compared to those who are not exclusively breastfed (Lestari et al, 2018). Optimal breastfeeding and complementary feeding practices are very important to prevent children from experiencing malnutrition (Walters et al, 2019).

This study is in line with Rakhmahayu et al. (2019) that infants who receive exclusive breastfeeding inhibit stunting by 2.04 times compared to babies who receive exclusive breastfeeding. Infants who are exclusively breastfed have a lower risk of stunting by 3.27 times (Abubakar et al, 2010).

\section{MP ASI is not on time and is stunting}

The results of the forest plot from the research article with a cross-sectional study design showed that children under five who did not receive complementary ASI not on time had a 2.46 times risk of increasing the incidence of stunting compared to children under five who received complementary feeding on time $(\mathrm{aOR}=2.46 ; 95 \% \mathrm{CI}=1.81$ to 3.36 ; $\mathrm{p}<0.000$ ).

There is a significant effect between timely complementary feeding and the incidence of stunting (Barir et al, 2019). The provision of complementary foods on time is one of the factors that influence the incidence of stunting (Ministry of the Republic of Indonesia, 2012). Complementary feeding of breastfeeding too early (less than 6 months) affects the occurrence of stunting and infectious diseases (diarrhea) (Akram et al, 2018).

This study is in line with Ilma et al. (2019) which showed the effect of complementary feeding with the incidence of stunting. Complementary feeding will reduce the risk of stunting in children. Research conducted by Humphrey et al (2018) is also in line with this study, which states that supplemental feeding increases linear growth and decreases stunting by $21 \%$.

\section{AUTHOR CONTRIBUTION}

Tyas Aisyah Putri, Yulia Lanti Retno Dewi, and Bhisma Murti, collected the data, measured the data, did data analysis, and wrote the paper.

\section{CONFLICT OF INTEREST}

There is no conflict of interest in this study. 
Putri et al./ Non Exclusive Breastfeeding, Complementary Feeding, and Stunting

\section{FUNDING AND SPONSORSHIP}

None.

ACKNOWLEDGEMENT

We are very grateful to the database providers PubMed, Google Scholar, and BMJ.

\section{REFERENCE}

Abeway S, Gebremichael B, Murugan R, Assefa M, Adinew YM (2018). Stunting and its determinants among children aged 6-59 months in Northern Ethiopia: A Cross-sectional study. Med J Nutrition Metab. 2018: 1078480. https://doi.org/10.1155/2018/1078480.

Abubakar A, Holding P, de Vijver FJR, Newton C, Van BA (2010). Children at risk for developmental delay can be recognized by stunting, being underweight, ill health, little maternal schooling or hight gravidity. J Child Psychol Psychiatry, 51(6): 652-659. https://doi.org/10.1111/j.1469-7610.2009.02193.x.

Akram RM, Sultana M, Ali N, Sheikh N, Sarker AR (2018). Prevalence and determinants of stunting among preschool children and its urban-rural disparities in Bangladesh. Food Nutr Bull, 163(4): 549-554. https://doi.org/10.1177/0379572118794770.

Alifariki LO, Rangki L, Hayati H, Rahmawati R, Sukurni S, Salma WO (2020). Risk factors of stunting in children age 24-59 months old. Semarang: Media Keperawatan Indonesia, 3(1). https://doi.org/10.26714/mki.3.1.202 0.10-16.

Barir B, Murti B, Pamungkasari EP (2019). The associations between exclusive breastfeeding, complementary feeding, and the risk of stunting in children under five years of age: A Path
Analysis Evidence from Jombang East Java. J Matern Child Health. 4(6): 486-498. https://doi.org/10.26911/thejmch.2019.04.06.09.

Fikadu T, Assegid S, Dube L (2014). Factors associated with stunting among children of age 24 to 59 months in Meskan District, Gurage Zone, South Ethiopia: A case-control study. BMC Public Health, 14: 80o. https://doi.org/10.1186/1471-2458-14-80o.

Kahssay M, Woldu E, Gebre A, Reddy S (2020). Determinants of stunting among children aged 6 to 59 months in Pastoral Community, Afar Region, North East Ethiopia: Unmatched Case Control Study. BMC Nutr, 6: 9. https://dx.doi.org/10.1186\%2Fs40795-020oo332-z.

Kementerian Kesehatan RI (2015). Kesehatan dalam Kerangka Sistainable Development Goals (Health in the Framework of Sustainable Development Goals) (SDG'S). Jakarta.

Kementerian Kesehatan RI (2018). Hari Gizi Nasional Ke-58: Cegah Stunting, Bersama Keluarga Kita Jaga 1000 Hari Pertama Kehidupan (58th National Nutrition Day: Preventing Stunting, Together with Families We Guard the First 1000 Days of Life). Jakarta: Kemenkes

Kramer MS, Kakuma R (2012). Optimal duration of exclusive breastfeeding. Chorane Library: Wiley.

Rakhmahayu A, Dewi YLR, Murti B (2019). Logistic regression analysis on the determinants of stunting among children aged 6-24 months in Purworejo Regency, Central Java. J Matern Child Health. 4(3): 158-169. https://doi.org/10.26911/thejmch.2019.04.03 .03.

Tadesse SE, Mekonnen TC, Adane M (2020). Priorities for intervention of 
Putri et al./ Non Exclusive Breastfeeding, Complementary Feeding, and Stunting

childhood stunting in Northeastern Ethiopia: A matched case-control study. PLoS ONE, 15(9). https://doi.org/10.1371/journal.pone.0239255.

Teferi MB, Hassen HY, Kebede A, Adugnaw E, Gebrekrstos G, Guesh M (2016). Prevalence of stunting and associated factors among children aged 06-59 months in Southwest Ethiopia: A cross-sectional study. J Nutr Health.
2020: 9520973 https://dx.doi.org/10$.1155 \% 2 \mathrm{~F} 2 \mathrm{O} 20 \% 2 \mathrm{~F} 9520973$.

Walters CN, Rakotomanana H, Komakeck JJ, Stroecker BJ (2019). Maternal determinants of optimal breastfeeding and complementary feeding and their association with child undernutrition in Malawi (2015-2016). BMC Public Health. 19, 1503 (2019). https://doi.org/10.1186/s12889-019-7877-8. 